\title{
Successful Treatment of Severe ARDS Developed After Lobectomy By Using Extracorporeal Membrane Oxygenation
}

\author{
Lobektomi Sonrası Gelişen Ağır ARDS’nin ECMO ile Başarılı \\ Tedavisi
}

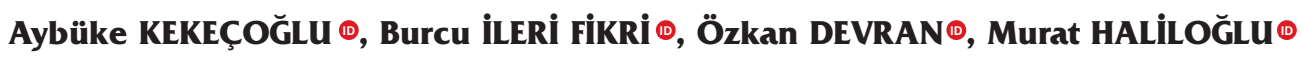

Cite as: Kekeçoğlu A, İleri Fikri B, Devran Ö, Haliloğlu M. Successful treatment of severe ARDS developed after lobectomy by using extracorporeal membrane oxygenation. İzmir Göğüs Hastanesi Dergisi. 2021;35(2):98-102.

\begin{abstract}
Pneumonia and acute respiratory distress syndrome (ARDS) are highly mortal complications following lobectomy. An effective treatment strategy is necessary in order to cure hipoxemia due to limited pulmonary reserve. Extracorporeal membrane oxygenation (ECMO) is an effective method to deal with hypoxemia; however the data about its use in severe ARDS after lobectomy is limited. In this case successful use of ECMO in a postoperative patient with pulmonary malignancy who developed severe ARDS is reported.
\end{abstract}

Keywords: ECMO, lobectomy, ARDS

Öz

Pnömoni ve akut respiratuvar distres sendromu (ARDS), lobektomi sonrası yüksek mortalite riski taşıyan komplikasyonlardır. Oluşan hipoksiyi tedavi etmek için etkili bir tedavi stratejisi gereklidir. Ekstrakorporeal membran oksijenizasyonu (extracorporeal membrane oxygenation, ECMO) hipoksinin tedavisinde etkili bir yöntemdir, ancak lobektomi sonrası ciddi ARDS'de kullanımı ile ilgili veriler oldukça kısıtıdır. Bu olguda akciğer kanseri nedeniyle opere edilen, sonrasında ciddi ARDS gelişen hastada ECMO'nun başarılı kullanımı rapor edilmiştir.

Anahtar kelimeler: ECMO, lobektomi, ARDS
Received/Geliș: 20.02.2021

Accepted/Kabul: 18.06 .2021

Published Online/Online Yayın: 06.08.2021

Corresponding author/Sorumlu yazar:

A. Kekeçoğlu

ORCID: 0000-0002-5589-6786

Yedikule Göğüs Hastalıkları ve

Göğüs Cerrahisi Eğitim Araştırma Hastanesi,

Solunum Yoğun Bakım Ünitesi İstanbul - Türkiye

aybuke-kekecoglu@hotmail.com

B. İleri Fikri

ORCID: 0000-0002-9220-5294

Başakşehir Çam ve Sakura Şehir Hastanesi, Yoğun Bakım Kliniği, İstanbul, Türkiye

ö. Devran

ORCID: 0000-0002-1498-8609 Yedikule Göğüs Hastalıkları ve Gögüs Cerrahisi Eğitim Araştırma Hastanesi, Solunum Yoğun Bakım Ünitesi

İstanbul, Türkiye

M. Haliloğlu

ORCID: 0000-0001-6597-2810

Sancaktepe Prof.dr. İlhan Varank Eğitim

Araștırma Hastanesi, Yoğun Bakım Ünitesi İstanbul, Türkiye

\section{INTRODUCTION}

ARDS is a life threatening complication in patients who underwent pulmonary resection. Due to lack of pulmonary reserve, pulmonary insufficiency is responsible for more than 70\% of total mortality in these patients ${ }^{(1)}$. ECMO is used as a life saving method in ARDS developed after trauma or pneumonia with no response to conventional therapies.

(c) Telif hakkı İzmir Göğüs Hastanesi'ne aittir. Logos Tıp Yayıncılık tarafından yayınlanmaktadır-

Bu dergide yayınlanan bütün makaleler Creative Commons 4.0 Uluslararası Lisansı (CC BY) ile lisanslanmıștır.

( ) Copyright İzmir Chest Hospital. This journal published by Logos Medical Publishing

Licenced by Creative Commons 4.0 International (CC BY) 
However malignancy is a relative contrindication for the use of ECMO; data about the use of ECMO in lung cancer patients is limited. In this case; successful use of ECMO in a patient who underwent lobectomy due to pulmonary malignancy and developed pneumonia related severe ARDS is reported.

\section{CASE REPORT}

An informed consent form was obtained from the patient before reporting this case. Videoassisted thoracic surgery (VATS) was performed to a 54- year -old male patient with a mass in the left pulmonary upper lobe which revealed to be a large cell neuroendocrine carcinoma combined with small cell carcinoma. The patient was then transferred to surgical ICU due to the development of ARDS.

Because of the deepening of hypoxia despite NIMV support, the patient was intubated and switched to invasive mechanical ventilation

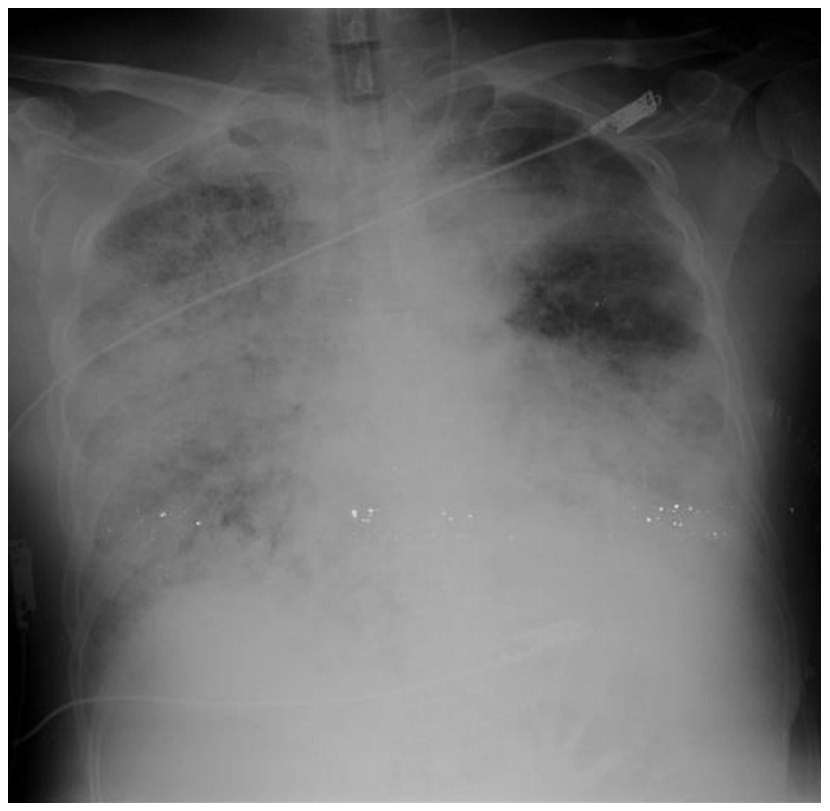

Figure 1. Chest X-ray before ECMO. support. The vital signs of the patient were as follows: arterial blood pressure, 135/63 mm Hg; heart rate was $102 \mathrm{bpm}$; and body temperature, $36,8^{\circ} \mathrm{C}$. Results of the hematological, and biochemical tests were as follows: hemoglobin, $9 \mathrm{gr} \mathrm{dL}^{-1}$, WBC $26,27 \mathrm{~mm}^{3}$, platelets, 298000 $\mathrm{mm}^{3}$; albumin, $2.2 \mathrm{gr} \mathrm{dL}^{-1}$; total bilirubin, $0.8 \mathrm{mg}$ $\mathrm{dL}^{-1}$, AST $58 \mathrm{IU} \mathrm{L}^{-1}$, ALT $33 \mathrm{IU} \mathrm{L}^{-1}$, LDH $673 \mathrm{IU} \mathrm{L}^{-1}$, BUN mg dL-1, creatinine $1.26 \mathrm{mg} \mathrm{dL}^{-1}$; CRP 198 $\mathrm{mg} \mathrm{dL}^{-1}$, and procalcitonine, $7.82 \mathrm{ng} \mathrm{ml}^{-1} \cdot \mathrm{PaO}_{2} /$ $\mathrm{FiO}_{2}$ was calculated as 41 . Disease progression was observed bilaterally in the areas of infiltration on chest X-ray (Figure 1). Despite protective mechanical ventilation for 6 hours, $\mathrm{PaO}_{2} / \mathrm{FiO}_{2}$ did not improve at all, then veno-venous(VV) ECMO treatment was started to the patient whose Murray score was 3,75.

Veno-venous ECMO was performed by using biocovered circuit through catheters inserted into both femoral veins. Venous blood was transferred using a 19 French (F) femoral catheter to the oxygenator blood pump and oxygenated blood

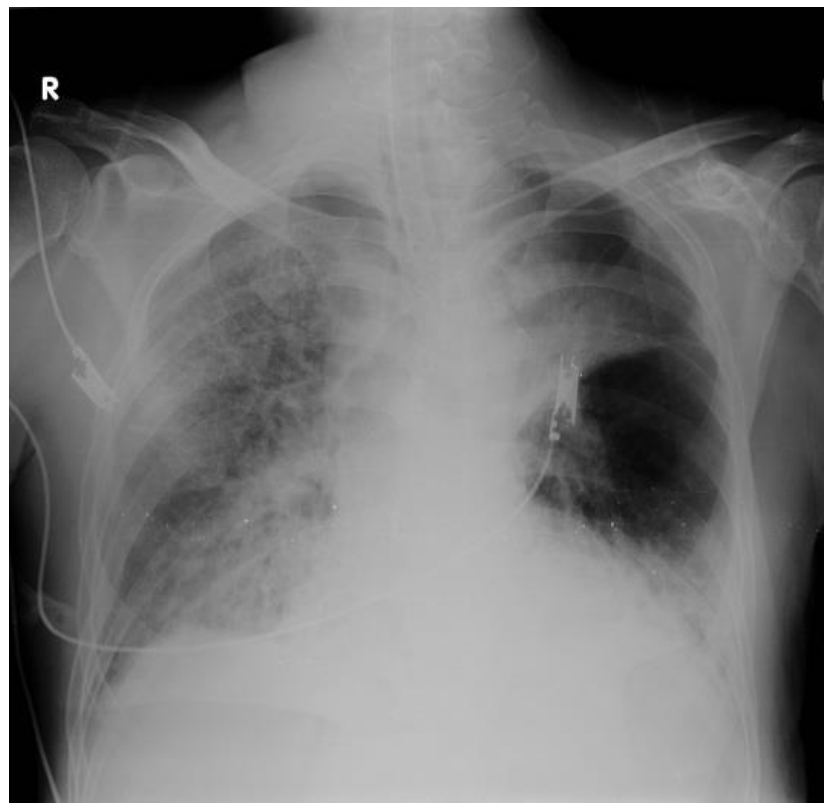

Figure 2. Chest X-ray after ECMO termination. 
was delivered using a $19 \mathrm{~F}$ femoral catheter through venous path. Gas exchange rate was $8 \mathrm{~L} \mathrm{~min}^{-1}$, initial $\mathrm{FiO}_{2}$ was $100 \%$, pump speed was 5 LPM, cardiac index was 3.5 min $\mathrm{m}^{2}$. Near-maximum flow rates are usually desired during VV ECMO to optimize oxygen delivery. In contrast, the flow rates used during veno arterial ECMO must be high enough to provide adequate perfusion pressure and venous oxyhemoglobin saturation, but low enough to provide sufficient preload to maintain left ventricular output.

The patient was given daily doses of $1 \mathrm{mg}$ IV methylprednisolone because of increased pulmonary fibroproliferation findings and sterile bronchoalveolar lavage samples. Improvements in chest X-ray, compliance and $\mathrm{SaO}_{2}$ indicated that the patient should be weaned from VVECMO. Weaning trials were performed by eliminating all countercurrent sweep gas through the oxygenator. Extracorporeal blood flow remained constant, but gas transfer did not occur. On the $11^{\text {th }}$ day, VV ECMO was terminated, and

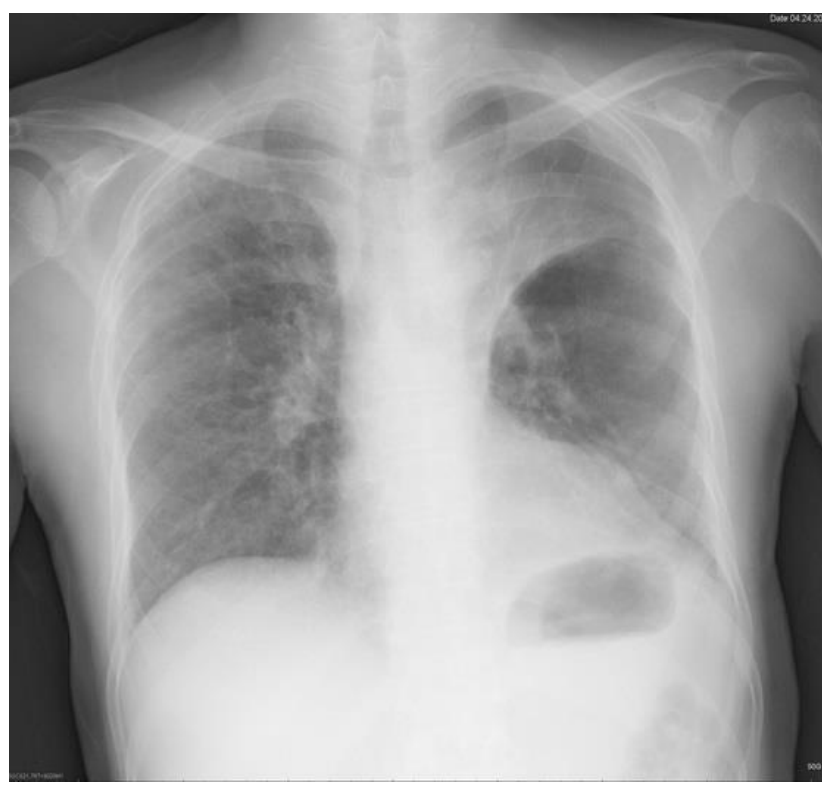

Figure 3. Chest X-ray at the day of discharge from intensive care. mechanical ventilator support was maintained (Figure 2). The patient was observed for 24 hours, during which the ventilator setting that were necessary to maintain adequate oxygenation and ventilation off ECMO were determined. Intravenous ampicillin-sulbactam (4x3 g) and colimycin (3x100 mg) were started for acinetobacter spp.based on culture results During follow-up, parenchymal infiltrations regressed. On the $26^{\text {th }}$ day, mechanical ventilator support was discontinued and oxygen supply was switched from T-tube. On $28^{\text {th }}$ day, the patient was decannulated and tracheostomy was terminated. On day 32 , the patient was discharged from the intensive care unit with $2 \mathrm{~L}$ $\min ^{-1}$ nasal oxygen therapy (Figure 3 ).

\section{DISCUSSION}

In this case report, we present a patient who underwent lobectomy for lung cancer and developed severe pneumonia-related ARDS. The administration of ECMO and concomitant steroid treatment dramatically improved lung and systemic organ function and survival.

The VV ECMO directs the patient's venous blood to the artificial gas exchanger, thereby to the life support system that provides oxygenation and removal of carbon dioxide. The blood flow is then directed to the arterial or venous circulation through central or peripheral cannulation.

ECMO is being used increasingly as a new treatment option in patients with ARDS who cannot achieve the target oxygen values despite the lung-protective ventilation strategy, or who cannot tolerate high carbon dioxide $\left(\mathrm{CO}_{2}\right)$ levels and low pH values, despite the development of high plateau pressures, and low tidal volume ${ }^{(2,3)}$.

Any condition that prevents the use of 
anticoagulation is typically considered an absolute contraindication to severe ARDS for ECMO. Patients receiving mechanical ventilation support at elevated pressures exceeding $30 \mathrm{~cm}$ $\mathrm{H}_{2} \mathrm{O}$ or elevated $\mathrm{FiO}_{2}$ values that may cause lung toxicity for more than 7 days are considered less likely to benefit from ECMO (2). Other relative contraindications include restrictions to vascular access that impede the insertion of the cannula, advanced malignancy, or severe and irreversible brain injury, in which the overall prognosis is unlikely to change.

In addition to reversing hypoxia, ECMO is also highly effective in reducing pulmonary immobilization and toxic inspiratory oxygen concentration. Pulmonary improvement can be accelerated by reversing hypoxic pulmonary hypertension and achieving pulmonary capillary perfusion under normal $\mathrm{PO}_{2}$ and $\mathrm{PCO}_{2}$ values (4). The risk of hemorrhage, one of the major complications of treatment, is relatively low in lobectomy patients. Although fibroproliferation can be reliably identified by open lung biopsy or gallium 67 screening, computed tomography and bronchoalveolar lavage have been suggested to be successful in differentiating fibroproliferation and secondary pneumonia in cases of prolonged ARDS ${ }^{(5)}$. Fibroproliferative changes triggered by the continuous production of proinflammatory mediators during ECMO may complicate the treatment of severe ARDS. Steroid therapy has been shown to have positive results in prolonged ARDS ${ }^{(5)}$. In these patients, decrease in the severity of lung injury (LIS) and multiple organ dysfunction syndrome (MODS) scores were reported after methylprednisolone treatment ${ }^{(6)}$. Methylprednisolone, inhibits inflammatory cell activation and reduces proinflammatory mediator release by stabilizing the alveolocapillary membrane resulting in alleviation of pulmonary inflammation and improvement in systemic organ function.

Based on this clinical case, earlier use of ECMO appears to be a life-saving option in patients with severe ARDS after lobectomy that does not respond to conventional treatments (such as low volume, low pressure, pulmonary protective ventilation or prone position). Steroid therapy may improve lung and systemic organ function in patients with ARDS in the fibroproliferative phase.

\section{CONCLUSION}

Pneumonia and acute respiratory distress syndrome are highly mortal complications following lobectomy. The data about the use of ECMO in lung cancer patients are limited. Due to lack of pulmonary reserve, pulmonary insufficiency is the reason for more than $70 \%$ of total mortality in these patients. We report this case because we thought that the case contributes to the literature by not only having pulmonary cancer but also having pulmonary resection.

Conflict of Interest: We have no conflict of interest that can cause of a possible bias.

Funding: We have no funding to declare.

Informed Consent: An informed patient consent was taken from the case before the study had begun.

\section{REFERENCES}

1. Kutlu CA, Williams EA, Evans TW, Pastorino U, Goldstraw P. Acute lung injury and acute respiratory distress syndrome after pulmonary resection. The Annals of Thoracic Surgery 2000;69:376-80. https://doi.org/10.1016/S0003-4975(99)01090-5

2. Force ADT, Ranieri V, Rubenfeld G. Acute respiratory distress syndrome. Jama 2012;307:2526-33. https://doi.org/10.1001/jama.2012.5669

3. Brodie D, Bacchetta M. Extracorporeal membrane 
oxygenation for ARDS in adults. New England Journal of Medicine 2011;365:1905-14.

https://doi.org/10.1056/NEJMct1 103720

4. Gattinoni L, Pesenti A, Bombino M, Pelosi P, Brazzi L. Role of extracorporeal circulation in adult respiratory distress syndrome management. New Horiz 1993;1:603-12.

5. Meduri GU, Belenchia JM, Estes RJ, Wunderink RG, El Torky M, Leeper Jr KV. Fibroproliferative phase of ARDS: clinical findings and effects of corticosteroids. Chest 1991;100(4):943-52.

https://doi.org/10.1378/chest.100.4.943

6. Meduri GU, Headley AS, Golden E, Carson SJ, Umberger RA, Kelso T, et al. Effect of prolonged methylprednisolone therapyin unresolving acute respiratory distresssyndrome: a randomized controlled trial. Jama 1998,280:159-65. https://doi.org/10.1001/jama.280.2.159 